\title{
Metal Ion Concentration within Algal Tissue of Species Growing in Proximity to Tioga River Outflows Affected by Acid Mine Drainage in Northern Pennsylvania
}

\author{
Cheyenne McKibbin, Kyle Root, and Gregory Carson \\ Department of Chemistry and Physics \\ Mansfield University \\ Mansfield, Pennsylvania 16933 USA
}

Received: May 30, 2009 Accepted: September 1, 2009

\begin{abstract}
In this study, two species of algae from two different areas impacted by acid mine drainage (AMD) were analyzed for metal ion accumulation. The two species of algae collected were Klebsormidium and Entransia. Both algal species are located in an area of high metal ion concentrations and low $\mathrm{pH}$ (ranging from 2.28 to 2.89). The study assessed the concentration of iron, manganese, zinc, copper and nickel in the algal tissue. Data shows that both Entransia and Klebsormidium are absorbing or adsorbing iron selectively.
\end{abstract}

\section{INTRODUCTION}

Acid mine drainage (AMD) is a serious problem in many parts of the world, typically in areas where extensive coal mining has occurred [1]. The Tioga River, located in Tioga County Pennsylvania, is situated atop the extreme Northeastern margins of the Appalachian bituminous coal beds. During the early 1900's several mining operations were active on the outskirts of the town of Blossburg. Presently, tributaries draining from these now abandoned mining areas deposit large amounts of manganese, iron and acidity into the Tioga River. Much of the water drainage comes from abandoned mineshafts. These abandoned mineshafts produce year-round outflow.

The leached pollutants from the abandoned mining areas have long been recognized as an environmental issue because of the negative impact they can have on the surrounding waterways and soils [1]. Efforts have been undertaken to contain and remove this type of pollution, but methods using physiochemical techniques such as ion exchange resins, precipitation, or electroplating have proved costly. Lower cost alternatives have been suggested such as using biosorbents, which have higher selectivity, greater loading capacity, and high availability have also be used [2].

Typically, for sequestration of divalent metal ions, fresh water algae has been found to be able to sequester $0.5-1.0$ millimoles of a given metal per gram of algae [3]. Various factors affect the uptake rates of algae however including $\mathrm{pH}$, competition of different metal ions, temperature, surface area/dry weight ratios, 
metal concentration, presence/thickness of mucilage (polysaccharides with small amounts of protein that have function group sites for metal binding), and whether or not the algae is living or dead [2-7]. Algae sequestration has been studied in both nature, where algae have been continuously exposed to high levels of metals, and in lab studies where cultures are usually grown first and then placed in contaminated conditions to measure metal accumulation. A natural algal mat consisting of the filamentous algae, Ulothrix, in the Yukon Territory has been shown to lower the concentration of iron in the water that flows over it by $90 \%$ (from $298 \mathrm{ppm}$ to $29.3 \mathrm{ppm}$ ), as well as having a large effect on other metal ion concentrations [6]. In another study, Klebsormidium in an algal mat was found to have a $4,016 \mathrm{mg} / \mathrm{kg}$ (dry weight) iron concentration whereas the surrounding waters had a $65 \mathrm{mg} / \mathrm{L}$ concentration suggesting some affinity for the metal at $\mathrm{pH}$ level above 3.00 [7].

\section{PURPOSE}

The purpose of this study was to investigate the relationship between the concentrations of metal ions found in water samples taken from AMD impacted areas and the metal ion concentrations found in the algae that populate these impacted areas. Specifically, the concentrations of iron, manganese, zinc, nickel, and copper were measured.

\section{METHODOLOGY AND PROCEDURES}

Two sample sites were selected for this study. The first site, Coal Creek, is a pool immediately outside an abandoned horizontal mineshaft; the pool is fed yearround by outflow from the mineshaft. The second site, Old 99, is a stream flowing from another abandoned horizontal mineshaft with year-round flow. The algae and water samples were collected during the Fall of
2007. Mineralogy is the same at each site: scattered deposits of pyrite, hematite, goethite, and marcasite in areas of mainly shale and sandstone. Water samples and samples of Klebsormidium were collected at Coal Creek, while water samples and samples of Entransia were collected at Old 99. Klebsormidium was not present at the Old 99 location and Entransia was not present at the Coal Creek location.

Water samples were collected in acid-washed plastic bottles. At the sample location, the collection bottles were rinsed once with the sample water before collecting the final sample. The $\mathrm{pH}$ values were measured on-site using a Hanna $\mathrm{pH}$ meter. Even with the low $\mathrm{pH}$ values at the sampling locations, $5 \mathrm{~mL}$ of concentrated nitric acid was added to each water sample to stabilize the metals present.

Once returned to the lab, the samples were refrigerated until ready for analysis. Before analysis was begun, the water samples were filtered through a 0.23 micrometer filter. After filtration, $25.0 \mathrm{~mL}$ of a $0.0063 \mathrm{M} \mathrm{CaCO}_{3}$ solution was added to $100.0 \mathrm{~mL}$ of each of the water samples to minimize $\mathrm{SiO}_{2}$ interference [8]. Once prepared, the samples were analyzed with a Perkin Elmer Atomic Absorption Spectrometer. Results are reported as ppm.

Algae samples were collected by grab samples. Grab samples were collected once at each location using acid-washed \#5 PP (polypropylene) containers to scoop up the substrate. The samples were returned to the lab where they were rinsed three times with distilled water. After draining off the excess water using a Buchner funnel, the samples were dried in an oven at 90.0 ${ }^{\circ} \mathrm{C}$ for 24 hours. $1.00 \mathrm{~g}$ of each of the dried samples was weighed into a mortar and pestle and ground for 5 minutes. After grinding, the samples were digested in hot concentrated nitric acid for several hours (5 $\mathrm{mL}$ aliquots of $\mathrm{HNO}_{3}$ were added with heating at $95^{\circ} \mathrm{C}$ ) until no more brown fumes were given off by the sample when excess nitric acid was added. 50\% hydrogen 
Table 1. Samples taken from Coal Creek $(\mathrm{pH}=2.23)$

\begin{tabular}{ccc}
\hline Metal lon & Water (in ppm) & $\begin{array}{c}\text { Algae (in ppm) } \\
\text { Klebsormidium }\end{array}$ \\
\hline $\mathbf{N i}$ & $0.050 \pm 0.001$ & $0.007 \pm 0.001$ \\
Co & $0.016 \pm 0.001$ & $0.000 \pm 0.001$ \\
Zn & $0.090 \pm 0.001$ & $0.020 \pm 0.001$ \\
Mn & $13.01 \pm 0.04$ & $0.315 \pm 0.005$ \\
Fe & $51.00 \pm 0.05$ & $38.08 \pm 0.08$ \\
\hline
\end{tabular}

Table 2. Samples taken from Old $99(\mathrm{pH}=2.89)$

\begin{tabular}{ccc}
\hline Metal Ions & Water (in ppm) & $\begin{array}{c}\text { Algae (in ppm) } \\
\text { Entransia }\end{array}$ \\
\hline $\mathrm{Ni}$ & $0.083 \pm 0.001$ & $0.017 \pm 0.002$ \\
Co & $0.046 \pm 0.001$ & $0.010 \pm 0.001$ \\
Zn & $0.153 \pm 0.001$ & $0.034 \pm 0.001$ \\
Mn & $26.31 \pm 0.01$ & $1.177 \pm 0.001$ \\
Fe & $0.73 \pm 0.02$ & $41.18 \pm 0.03$ \\
\hline
\end{tabular}

peroxide was added in $1.0 \mathrm{~mL}$ aliquots with gentle heating until the effervescence subsided and the appearance of the samples remained unchanged. Once completed, $5.0 \mathrm{~mL}$ of concentrated hydrochloric acid was added to both samples. Each solution was then diluted to a final volume of $100.0 \mathrm{~mL}$ using volumetric flasks. The samples were filtered through a 0.23 micrometer filter before analysis as described above for the water analysis.

\section{RESULTS AND DISCUSSION}

a. Water Chemistry

At both Coal Creek and Old 99 locations, there is little contamination by nickel, cobalt or zinc (see Tables 1 \& 2).. All species measure in the fraction of a ppm range although, of the three, zinc is present in the largest amount and cobalt in the smallest. The acidity $\left(\mathrm{H}^{+}\right.$concentration) at the Coal Creek location is about 4.5 times 
higher than at the Old 99 location. Measurements of the $\mathrm{pH}$ at these locations during different times of the year indicate that $\mathrm{pH}$ levels are constant (within 0.1 to 0.2 units) throughout the year. Since the $\mathrm{pH}$ levels remain constant it has not been possible to study in situ how these metal ion concentrations might change as $\mathrm{pH}$ changes.

As previously reported [9], Coal Creek contains a substantial amount of manganese and iron due to the oxidation of both iron and manganese pyrites:

$$
\begin{aligned}
& 4 \mathrm{FeS}_{2}+15 \mathrm{O}_{2}+14 \mathrm{H}_{2} \mathrm{O} \rightarrow \\
& 4 \mathrm{Fe}(\mathrm{OH})_{3}+16 \mathrm{H}^{+}+8 \mathrm{SO}_{4}^{-2} \\
& 2 \mathrm{MnS}_{2}+7 \mathrm{O}_{2}+2 \mathrm{H}_{2} \mathrm{O} \rightarrow \\
& 2 \mathrm{Mn}^{+2}+4 \mathrm{SO}_{4}^{-2}+4 \mathrm{H}^{+}
\end{aligned}
$$

Due to the difference in concentrations, it is surmised that at the Coal Creek location deposits of iron pyrite exceed that of manganese pyrite.

At the Old 99 location the concentrations of iron and manganese appear to be reversed. The manganese concentration in the water at Old 99 is clearly at a higher concentration when compared to the concentration of the iron in the water. In a previous study [9], we concluded that manganese pyrite must be more prevalent than iron pyrite at the Old 99 location to account for such a difference in the concentrations of manganese and iron measured. When studies were conducted on the concentration of these ions in the filamentous algae present at both locations, however, a very different picture came into focus.

\section{b. Algae}

As with the water samples taken from Coal Creek and Old 99 the concentrations of nickel, zinc and cobalt measured within the algal species, Klebsormidium and Entransia, are also relatively small. It should be noted here that the concentrations of all three metal ions in the algae are dramatically less than their concentrations measured in the water.

The concentrations of both manganese and iron in the Klebsormidium are lower than in the water samples taken from Coal Creek, with the iron concentration in the water being higher than the manganese concentration. One of the interesting things that we observed was the concentration of iron in the Klebsormidium algae samples. Whereas the concentration of the other metal ions in the water are 5-41 times higher than in the algae, the concentration of iron in the water is only 1.5 times as high as the iron concentration in the algae. The Klebsormidium appears to be picking up the iron from the water, which has been observed in other studies [7].

We observed similar behavior in the concentrations of the metals other than iron in the Entransia algae samples. The concentrations of the metal ions in the water are 4-22 times higher than in the algae.

When examining the Entransia and water data at Old 99 two interesting observations were made with respect to the iron and manganese concentrations. First, in our original study [9], which measured the concentration of metal ions in water samples, but not in algae, we surmised that the area around Old 99 contained more manganese pyrite deposits compared to iron pyrite based on the fact that the manganese concentration was so much higher than the iron concentration in the water. However, when the Entransia algae was analyzed from Old 99 we discovered that, in fact, the iron concentration in the Entransia and water combined were higher than the manganese concentration in the Entransia and water combined. We now surmise that that the area does not contain more manganese pyrite deposits than iron pyrite; the iron was simply in a place where we did not look for it in the previous study [9].

The second interesting observation came when we compared the amounts of iron present in the water and Entransia 
samples taken from Old 99. The iron concentration in the Entransia was 56 times higher than the iron concentration in the water. At this time, the method by which Entransia is removing iron from the water is unclear, what is clear at this point is that Entransia is somehow removing iron from the water. We cannot say at this point whether the iron is being absorbed into the Entransia on adsorbed onto the Entransia. The process by which the removal of iron is occurring (adsorption or absorbtion) is currently being investigated.

It should be noted again that since the measurement of the $\mathrm{pH}$ 's at these two locations is essentially constant during the year it has not been possible to study how changes in $\mathrm{pH}$ affect the metal ion

\section{CONCLUSIONS}

The possibility of Entransia and
Klebsormidium sequestering iron
preferentially is being investigated further. Uptake studies using Entransia and Klebsormidium and iron are currently underway. The affect of $\mathrm{pH}$ on the ability of these algae to sequester iorn is also being examined. If, in fact, Entranisa and Klebsormidium preferentially sequester iron, the pathway for such uptake will need to be investigated. Preliminary uptake studies do not seem to support the hypothesis that the iron is merely adsorbed onto the algal surfaces; it appears that the iron is being absorbed into the algae. If Entransia and Klebsormidium are taking up iron with purpose, such as part of a metabolic pathway or for use in a structural compound, this could possibly be used in bioremediation techniques. Depositing Entransia or Klebsormidium into aquatic environments where there is a high concentration of iron, allowing the algae to grow, and then harvesting the algae before it dies and releases its cellular contents would be a cost- and labor-saving remediation of one of the dangerous factors of AMD. Further studies could also be done to isolate other algae that have the same pathways and uptake of different metal ions. If algae can be found that specifically sequester dangerous heavy metals, new bioremediation techniques can begin to be employed.

\section{ACKNOWLEDGEMENTS}

The authors would also like to acknowledge the Mansfield University Faculty Professional Development Committee for the funds provided which supported this undergraduate research project.

\section{REFERENCES}

1. Spiro, T., and W. Stigliani, Chemistry of the Environment (2nd ed.), (Prentice Hall: Upper Saddle River, New Jersey, 2003).

2. Tien. C.J., "Biosorption of Metal lons by Freshwater Algae with Different Surface Characteristics," Process Biochemistry, 38: 605-613, (2002).

3. $\mathrm{Yu}, \mathrm{Q}$., Matheickal, P.Y, and Kaewsarn, P. "Heavy Metal Uptake Capacities of Common Marine Macro Algal Biomass," Water Research, 33: 1534-1537, (1999).

4. Foster, P.L., "Species Associations and Metal Contents of Algae from Rivers Polluted by Heavy Metals," Freshwater Biology 12: 17-39, (1982)

5. Hargriavis J. W., and Whitton, B.A., "Effect of pH on Growth of Acid Stream Algae," British Phycological Journal, 11: 215-223, (1976).

6. Lawrence, J,R., Sworhone, G.D.W, and Kwong, Y.T.J., "Natural Attenuation of Aqueous Metal Contamination by an Algal Mat," Canadian Journal of Microbiology, 44: 825-832, (1998).

7. Stevens A.E., McCarthy B.C, and Morgan, L., "Metal Content of Klebsormidium - Dominated Algal Mats from Acid Mine Drainage Waters in Southeastern Ohio," Journal of the Torrey Botanical Society, 128(3): 226233, (2001).

8. Eaton, A.D., Clesceri, L.S., and Greenberg, A.E., Standard Methods for 
the Examination of Water and Wastewater, $\left(19^{\text {th }}\right.$ ed.), (American Public Health Association, American Water Works Association, Water Environment Federation, Washington D.C., 1995)
9. Gangong C., Carson, G., and Kirby, J., "Using Meiobenthic Species as a Measure of the Impact of Acid Mine Outflows on the Tioga River in North Central Pennsylvania," American Journal of Undergraduate Research, 6: 1-6, (2007).

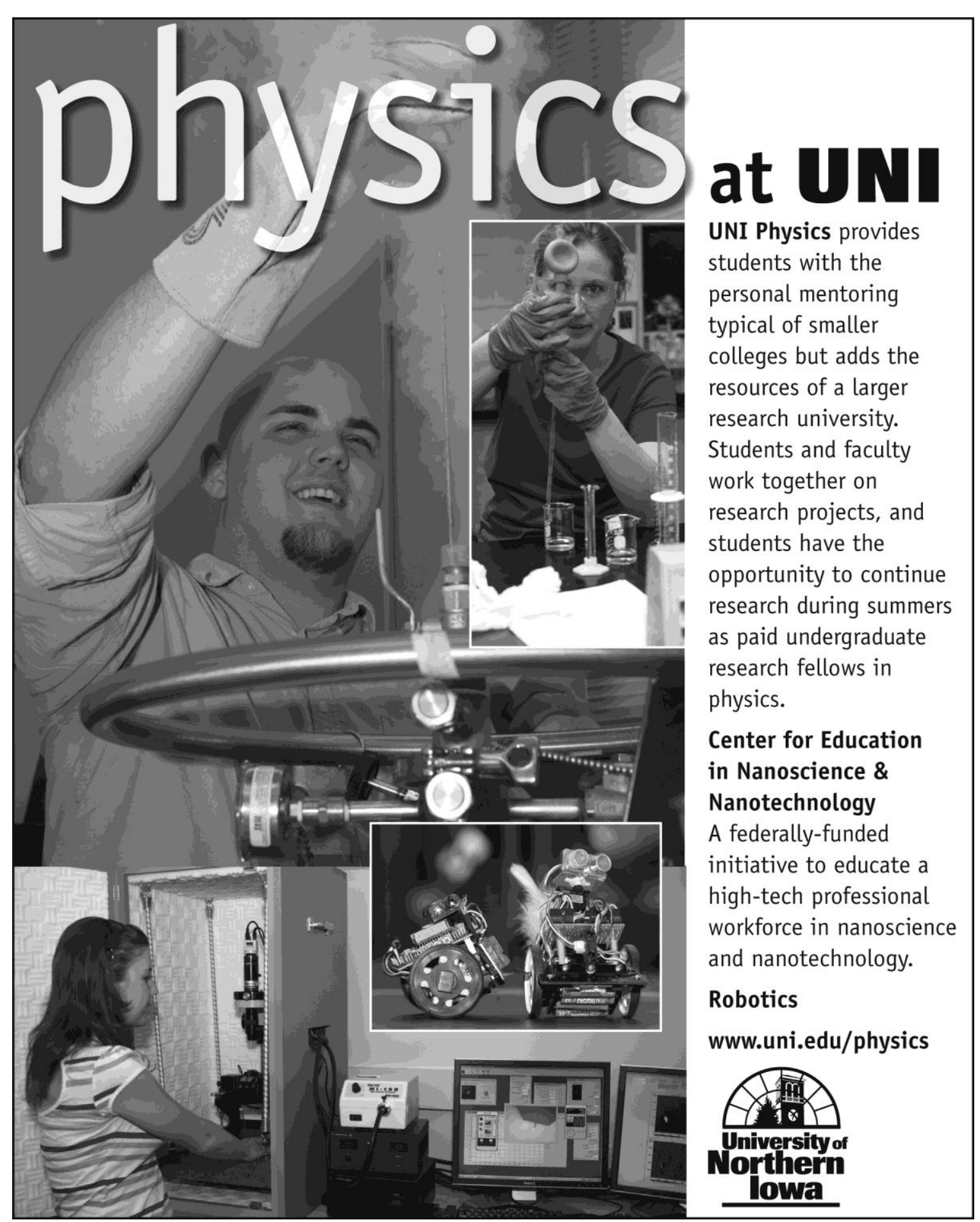

